\title{
Histopathological effects of trypanorhynch metacestodes in the digestive gland of a novel host, Carcinus maenas (Decapoda)
}

\author{
R. H. Gurney ${ }^{1, *}$, B. F. Nowak ${ }^{2}$, I. Dykova ${ }^{3}$, A. M. Kuris ${ }^{4}$ \\ ${ }^{1}$ CSIRO Marine Research Laboratories, GPO Box 1538, Hobart, Tasmania 7001, Australia \\ ${ }^{2}$ School of Aquaculture, Tasmanian Aquaculture and Fisheries Institute, University of Tasmania, Launceston, \\ Tasmania 7250, Australia \\ ${ }^{3}$ Institute of Parasitology, Academy of Sciences of the Czech Republic, Branišovká 31, 37005 České Budějovice, \\ Czech Republic \\ ${ }^{4}$ Department of Ecology, Evolution and Marine Biology and Marine Science Institute, University of California, \\ Santa Barbara, California 93106, USA
}

\begin{abstract}
The green crab Carcinus maenas was introduced to Australian temperate waters in the late 1800s, has since become established, and is now considered to be a pest. We undertook an extensive parasite survey to find potential natural enemies of $C$. maenas and found it to be infected in Australia by 2 species of larval trypanorhynch tapeworm, Trimacracanthus aetobatidis and Dollfusiella martini. We describe the gross pathology and histopathology of the parasites' new host (C. maenas) and note that the plerocercoid larvae are located in the lumen of the digestive gland tubules. The presence of $D$. martini in $C$. maenas with low population numbers suggests that either $D$. martini has an impact (direct or indirect) on the survival of C. maenas, or that the parasite may be an indicator of high predation pressure. If the former were true, this would contribute to the control of this introduced pest species.
\end{abstract}

KEY WORDS: Trypanorhynch $\cdot$ Carcinus maenas $\cdot$ Biological control $\cdot$ Crustacean pathology

\section{INTRODUCTION}

The green crab Carcinus maenas, a native of the Atlantic coast of Europe, has been introduced to North America, South Africa and Australia, where it is recognised as an invasive pest (Tettlebach 1986). A related Mediterranean species, C. aestuarii, has become established in Japan (Geller et al. 1997). Both Carcinus species are generalist predators, with an appetite for bivalves, gastropods and other invertebrate infauna. Apart from directly threatening prey species, C. maenas has the potential to change the structure of native communities (Le Roux et al. 1990, Grosholz \& Ruiz 1995, MacKinnon 1997, Walton 1997), and may even affect the abundance, demography and behaviour of migratory shorebirds (Ruiz 1987).
Species which have been introduced to new environments are often more successful than they were in their native environments (provided the new environment is suitable for growth and reproduction), in part because they have escaped the natural predators, parasites and diseases of their endemic range (Torchin et al. 2001, 2003). Support for this hypothesis has been provided by Kuris \& Gurney (in press), who surveyed green crabs Carcinus maenas and native crabs in Australian temperate waters, and found green crabs to be relatively free of parasites compared to related (Nectocarcinus integrifrons) and ecologically similar (Grapsidae) crabs.

However, at one site (Swan Bay, Victoria), green crabs were heavily parasitised by larval tapeworms, and at this site (unlike other areas in Australia) the 
green crabs were less abundant compared to other crabs. Here, numbers were so low that the standard sampling protocol (baited traps left overnight) had to be abandoned and the area searched exhaustively to catch a small number of green crabs. Native crab numbers at this site were also relatively low but were, nonetheless, well represented by 5 crab families. A possible reason for the low abundance of green crabs at this site may be due to the pathology of the digestive gland caused by trypanorhynch tapeworm metacestodes. If this hypothesis is correct, then the tapeworms might aid control of green crab populations in temperate Australian waters.

Biological control of Carcinus maenas using trypanorhynch tapeworms will be difficult due, in part, to the trophic transmission of the parasite which involves a number of hosts. The life cycle of both Dollfusiella martini and Trimacracanthus aetobatidis is still to be elucidated; however, if these species of trypanorhynch develop through a free swimming coracidia stage, they may well follow a life cycle similar to that of the trypanorhynch Lacistorhynchus tenuis, reported by Sakanari \& Moser (1989). This would involve the coracidia of $D$. martini and $T$. aetobatidis infecting a copepod as the first intermediate host. The copepod would then, in turn, be consumed by a crab, in this case C. maenas, where the tapeworms develop into plerocercoids, and C. maenas becoming the second intermediate host. C. maenas would in turn be eaten by shallow water

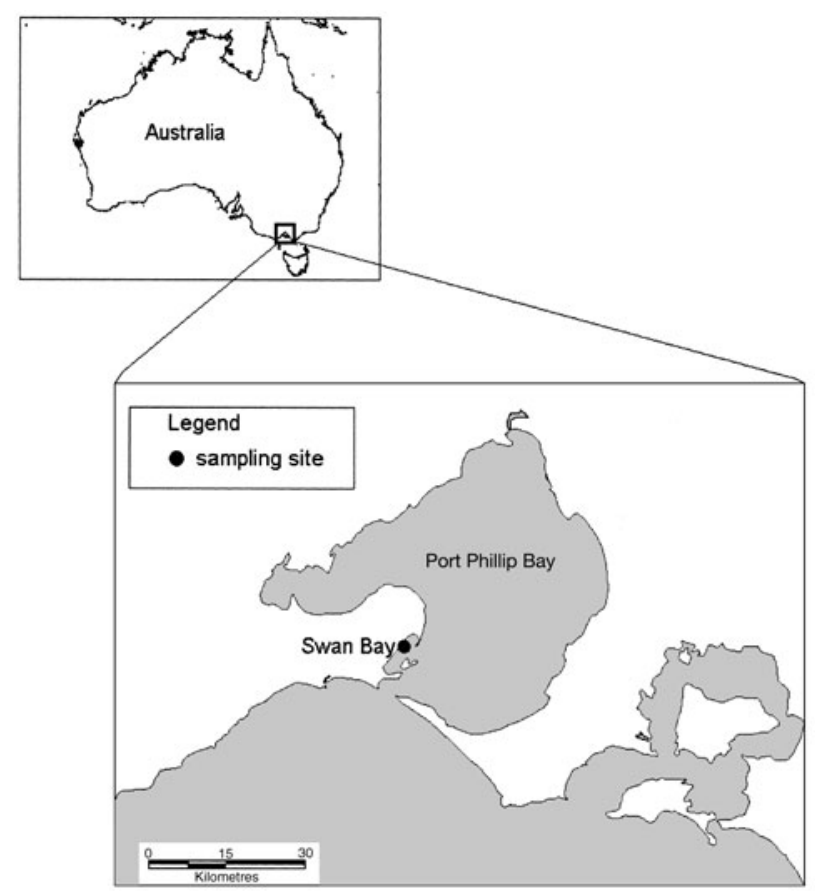

Fig. 1. Carcinus maenas sampling site at Swan Bay, Victoria rays and sharks, where the plerocercoids excyst and develop into adult tapeworms living in the spiral valves of the final host.

Parasites with complex life cycles involving more than 1 host present a number of problems for biological control. The most obvious problem is that if an intermediate host is removed from the chain of trophic transmission, the final host will not be attacked or infected. Another problem relates to ensuring the specificity of the parasite in relation to a number of hosts instead of a single final host. Parasitoids, for example, have often proved to be successful biological control agents, in part because they have a simple and direct life cycle involving a single specific host.

Few reports of the pathology produced by trypanorhynchs in their final and intermediate hosts are available. Adult trypanorhynch tapeworms only occur in the spiral valves of elasmobranchs (Roberts \& Janovy 1996). Their range of intermediate hosts, however, is much greater: it includes bony fishes, molluscs and crustaceans (Cake 1976, Palm 1997). In this paper we describe the histopathological effects of the larval stages of the trypanorhynch cestodes Dollfusiella martini and Trimacracanthus aetobatidis (Beveridge \& Campbell 1987, Beveridge 1990) on the digestive gland of Carcinus maenas from Swan Bay, Victoria.

\section{MATERIALS AND METHODS}

In a preliminary survey, 43 adult Carcinus maenas were collected from Swan Bay within Port Phillip Bay, Victoria $\left(144^{\circ} 39^{\prime} 47^{\prime \prime} \mathrm{E}, 38^{\circ} 13^{\prime} \mathrm{8}^{\prime \prime} \mathrm{S}\right)$ in November 1996 (Fig. 1). They were collected by hand from areas underneath rocks at low tide and were taken live to the laboratory. The crabs were dissected by detaching the carapace to expose the body cavity, and the number of trypanorhynchs were counted. On 16 July 1999, 15 C. maenas from the same site were collected, and part of the digestive gland was removed and placed in seawater Davidson's fixative (Bell \& Lightner 1988). The tissue was transferred to $70 \%$ ethanol after $7 \mathrm{~d}$ and later processed for histology and sectioned at 6 $\mu \mathrm{m}$. Sections were stained with hematoxylin and eosin (H\&E), Masson's trichrome (Bradbury \& Gordon 1991), PAS (periodic acid-Schiff reaction; Cook 1991) and Von Kossa's reaction for calcareous corpuscles (Page et al. 1991). In histological sections, parasite density was scored as absent, light (1 worm per section), moderate ( 2 to 3 worms per section) or heavy ( $>3$ worms per section).

To identify the trypanorhynchs the entire larvae were placed in tap water to evert the proboscides for identification, and were then fixed in AFA (alcoholformalin-acetic acid). 


\section{RESULTS}

Two trypanorhynch species were found, Dollfusiella martini and Trimacracanthus aetobatidis. Their prevalences and intensities were 84 and $48 \%$, and 8.8 and 2.2 , respectively.

\section{Gross pathology}

The digestive glands of lightly infected green crabs appeared normal, a glossy dark green colour, whereas the digestive glands of heavily infected crabs were a pale cream colour and speckled with black granules 0.5 to $1 \mathrm{~mm}$ long. Encapsulated worms were clearly visible within distended hepatopancreatic tubules. Dollfusiella martini appeared predominantly in the antero-dorsal segment of the digestive gland near the juncture of the cardiac stomach and midgut intestine, while Trimacracanthus aetobatidis plerocercoids were present mainly in the subcardiac sternal pocket of the thoracic sterna, anterior to the thoracic ganglion and ventral to the cardiac stomach.

\section{Histology}

The trypanorhynch species could be distinguished in sections. Dollfusiella martini was small (400 to $450 \mu \mathrm{m})$ and possessed large microtriches (Figs. 2 \& 3). Trimacracanthus aetobatidis was larger (1100 to $1300 \mu \mathrm{m}$ ) and had a thick folded tegument without visible microtriches (Figs. 2, 3 \& 4). The 2 species stimulated similar host responses. Most of the following description relates to $D$. martini as it was more prevalent: only well-developed plerocercoids were observed, and all were contained within the digestive tubules. There was no evidence of migration into or out of host tissues. The surfaces of both species of worm were in direct contact with the tubule epithelium of the host's digestive gland; there was no sheath enveloping the worm or separating it from the host (Fig. 6). Metaplasia of tubule epithelium was evident where the worms came into contact with the tubule. At these sites the normal cell population was gradually configured into a single layer of cuboidal and finally squamous cells, which were so highly compressed that the nuclei become spindle-shaped. In addition to the tubular changes, which included atrophy and necrosis of epithelium, there was a loss of surrounding secretory parenchyma due to the pressure atrophy caused by dilated tubuli (Figs. 7 \& 8). Longitudinal sections of tubules infected by both species of worm showed that distally or proximally to the worm, the tubule cells resumed their characteristic shape and resorptive (R-) cells reappeared (Fig. 6). This contrasted with uninfected tubules, where the embryonic (E-), blisterlike (B-), fibrillar (F-) and R-cells, according to the schema of Jacobs (1928), were discernible in uninfected tubules, with Bcells being particularly abundant.

Pronounced inflammatory changes in the interstitium were observed in several cases where dense accumulations of haemocytes infiltrated the connective tissue surrounding the infected tubules (Figs. $9 \& 11$ ). Granulomatous inflammatory reactions also occurred around tubules which had lost their integrity (Fig. 10) or where signs of degeneration, death or complete necrosis of plerocercoids occurred (Fig. 12). Granulomatous lesions surrounded by pigmented layers were observed in most infected specimens. Typical granulomas, with a necrotic centre and a thick layer of newly formed granulation tissue (Fig. 13) on the periphery, were also observed. These granulomas probably related to plerocercoid infection, but neither calcareous corpuscles, characteristic for the parenchyma of cestodes, nor calcareous hooks of the tentacles where observed in necrotic material.

Large numbers of haemocytes aggregated around infected tubules and, in particular, around melanised bodies (Figs. 12 \& 14). Spherical eosinophilic cells, 35 to $40 \mu \mathrm{m}$ in diameter, were associated with the haemocyte aggregations. The nucleii of these cells were positioned on the outer edge of the cell wall (Fig. 11). Light infections of either species of worm did not stimulate an inflammatory response. Individual worms occupied digestive tubules, but no aggregation of haemocytes surrounded the infected tubule.

The black specks observed in gross pathology were too small to be intact metacestodes; they more closely resembled the shrivelled and melanised remains of digestive tubules with the hollow centre corresponding to the tubule lumen. Furthermore, the histological sections stained with Von Kossa's reaction did not indicate the presence of either the hooks of the proboscides or calcareous corpuscles of worms in these melanised structures. These melanised specks were always in the same location, and were in direct contact with regions of the digestive gland containing heavy infections of Dollfusiella martini plerocercoids, suggesting that they were the remnants of necrotic tubules damaged by cestode infection.

The digestive gland tissue of lightly infected and uninfected crabs showed very little staining with PAS; however, moderately and heavily infected crabs were darkly stained. In heavily infected green crabs, PAS positive material was concentrated distally and proximally in R-cells. Some congealed clumping of PASpositive material also occurred in connective tissue between the tubules. Sectioned worms within the infected digestive gland were strongly PAS-positive, as were the melanised bodies described above. 

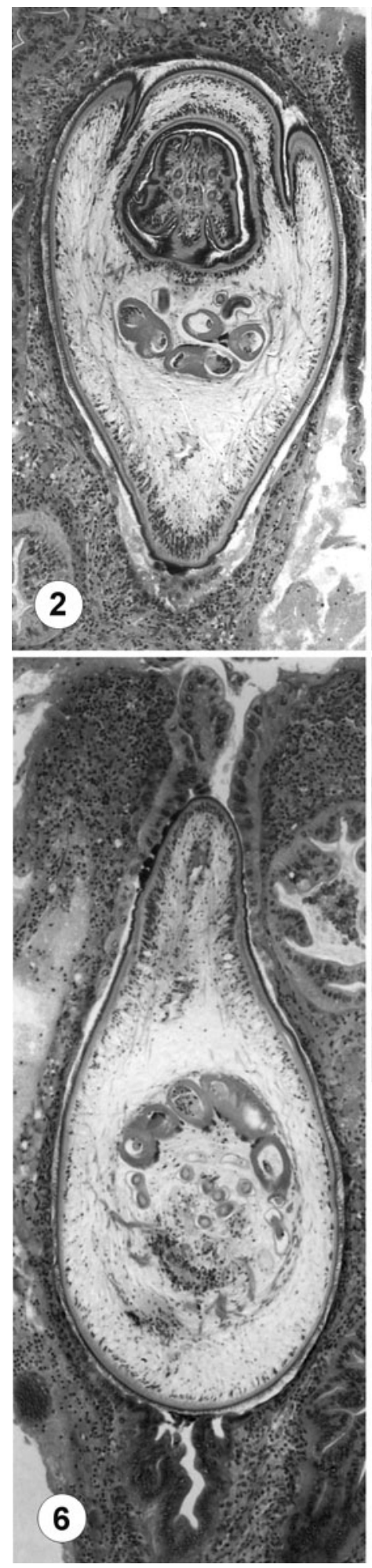
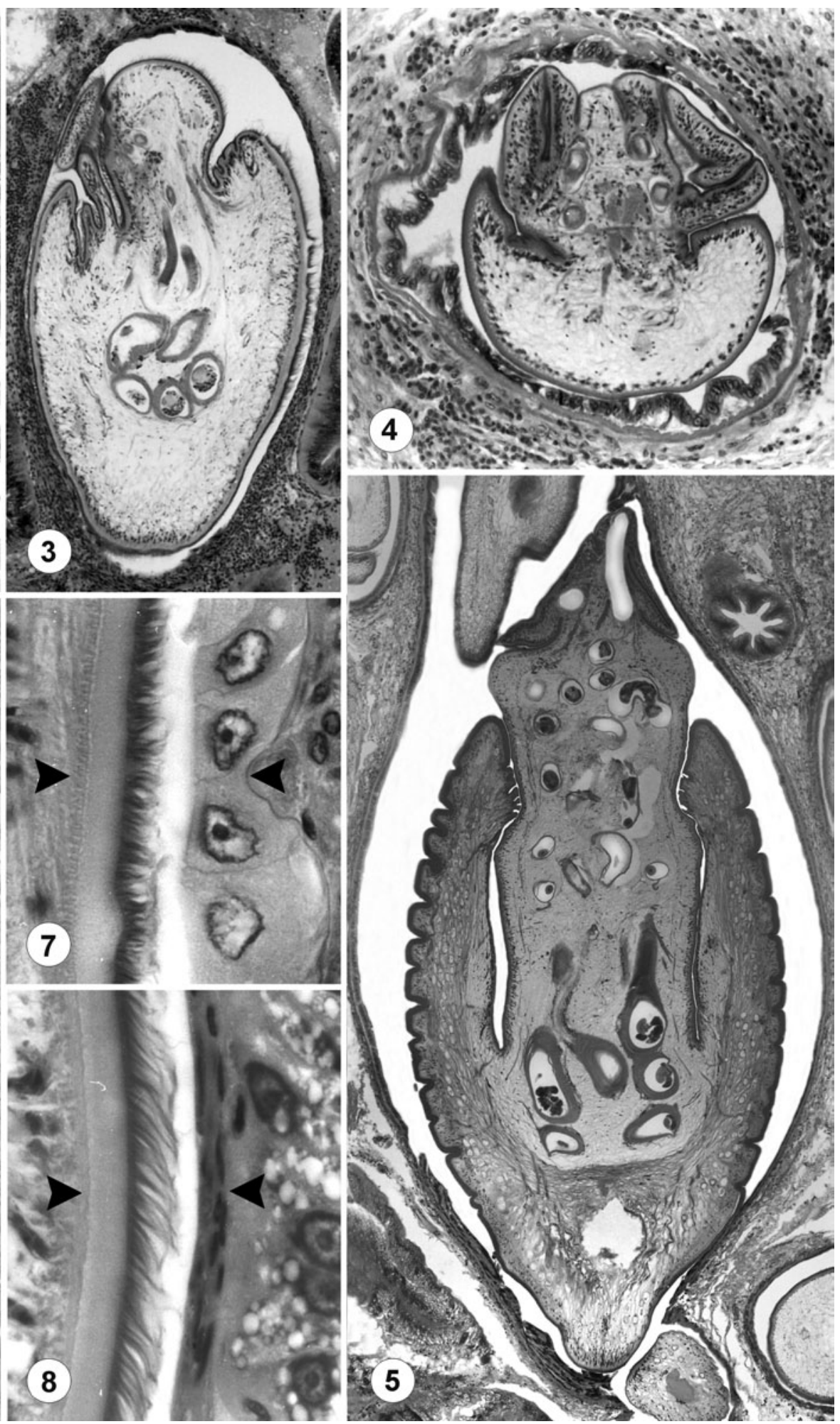

Figs. 2 to 8. Dollfusiella martini and Trimacranthus aetobatidis infecting Carcinus maenas. Figs. 2 \& 3. D. martini plerocercoids in the digestive glands of $C$. maenas. Plerocercoids are localised in distended tubules (H\&E stain, $\times 35)$. Fig. 4. Cross-section of $D$. martini anterior, showing bothridia and inverted scolex. Tubular epithelium partly atrophied (H\&E, $\times 150)$. Fig. 5. T. aetobatidis plerocercoid in the digestive gland tubule of $C$. maenas $(\mathrm{H} \& \mathrm{E}, \times 20)$. Fig. 6. Plerocercoid growth, which has produced pronounced hypobiotic changes of tubule epithelium around the most voluminous part of the plerocercoid, while tubule epithelium remains normal in segments distal and proximal to the plerocercoid (H\&E, $\times 35)$. Figs. $7 \& 8$. Host-parasite interface. Left arrows mark tegument of plerocercoids with filamentous microtriches; right arrows mark flattened epithelial tissue of host digestive gland tubule $(\mathrm{H} \& \mathrm{E}, \times 500)$ 

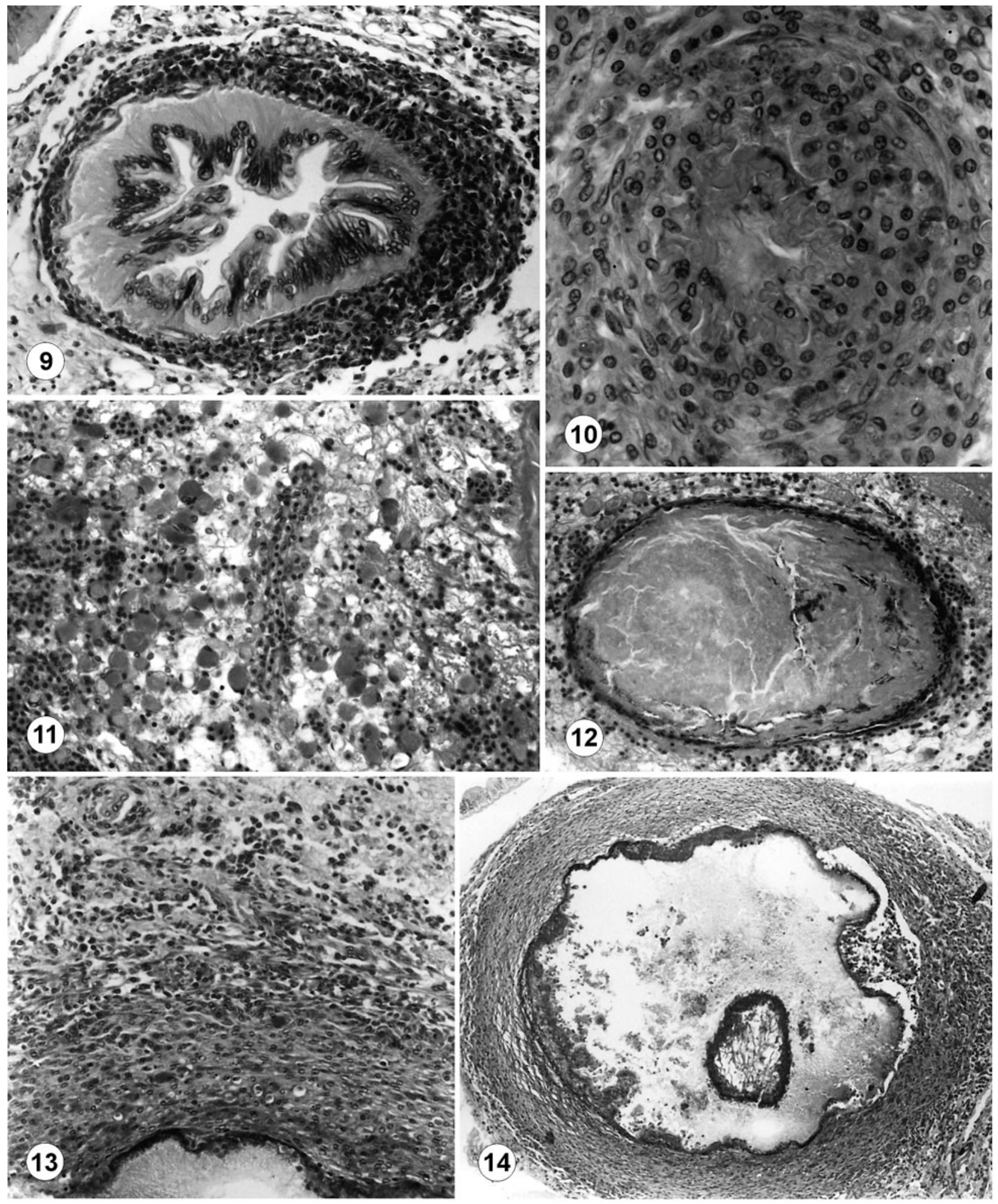

Figs. 9 to 14. Dollfusiella martini infecting Carcinus maenas. Fig. 9. Inflammatory reaction surrounding a digestive gland tubule. The neighbouring segment is occupied by a plerocercoid $(\mathrm{H} \overline{\& \mathrm{E}, \times 170})$. Fig. 10. Early granulomatous lesion surrounding a digestive gland tubule which has lost integrity $(\mathrm{H} \& \mathrm{E}, \times 500)$. Fig. 11. Inflammatory infiltration of digestive gland tissue with predominating 'eosinophilic cells' $(\mathrm{H} \& \mathrm{E}, \times 170)$. Fig. 12. A former digestive gland tubule containing necrotic material contained within a thin layer of connective tissue $(\mathrm{H} \& \mathrm{E}, \times \overline{35})$. Figs. $13 \& 14$. Granulomas surrounded by newly formed granulation tissue on the periphery $(H \& E, \times 170 ; H \& E, \times 30)$ 


\section{DISCUSSION}

Lesions developed in tissues adjacent to plerocercoids within the tubules. We think the pressure exerted by growing metacestodes upon the epithelial tissue of the infected tubules caused distention of the tubules, producing epithelial metaplasia and loss of surrounding secretory parenchyma. The extent of lesions in the digestive gland tissue was directly related to the intensity of tubule infection. Light infections were not associated with histological changes, while heavy infections were clearly pathenogenic, supporting our gross observations of lightly infected digestive glands appearing normal in colour versus heavily infected digestive glands being cream. The absence of immature plerocercoids suggests that the lightly infected crabs had been infected for some time without showing pathological signs or evidence of a strong immune response.

The green crabs' response to trypanorhynch infection in this study was typical of the Crustacea: it involved haemocyte aggregation, encapsulation and melanisation (Ratna \& Vinson 1983, Soderhall \& Cerenius 1992). The metacestode infection induced transformation of the tubule cells (recognisable E-, F-, Rand B-cells) into compressed squamous cells. At some point the plerocercoid died or was killed within the tubule, producing the necrotic highly PAS-positive material. Haemocytes aggregated around the infected tubule and produced a tight, multilayered capsule of fibrocytes, which in turn deposited melanin. Concentric encapsulation followed by melanisation occurred in the crayfish Cherax quadricarinatus hepatopancreatic tubules infected with intracellular rickettsiae (Owens et al. 1992).

An endemic crab, Nectocarcinus integrifrons, is also parasitised by Trimacracanthus aetobatidis and Dollfusiella martini (A. M. Kuris \& R. H. Gurney unpubl. data). However, little melanisation occurs in the digestive gland of heavily infected native crabs. Since $N$. integrifrons probably evolved in the presence of both species of trypanorhynch worms, an attenuated inflammatory reaction might be an evolutionary response. This would appear to be adaptive, as the stronger host response of the naive green crab presumably causes more disruption to digestive gland function than in the evolved host.

PAS staining suggested higher levels of glycogen in the digestive gland of crabs that were heavily infected with trypanorhynch metacestodes than in lightly or uninfected crabs. The grapsid crab Chasmagnathus granulata infected with metacercariae was found to contain more glycogen than uninfected $C$. granulata (Robaldo et al. 1999). The infiltration of infected tissue with glycogen-rich haemocytes may explain the increased glycogen levels in infected crabs (Robaldo et al. 1999).

The digestive gland performs a range of important physiological functions and is a vital organ in Crustacea. It synthesises and secretes digestive enzymes, absorbs nutrients, is directly involved in excretion, moulting, storage of organic reserves and the metabolism of lipids and carbohydrates (Gibson \& Barker 1979). These functions are likely to be severely impaired by heavy infections with trypanorhynch metacestodes. High-intensity infections reduce the numbers of intact tubules, damage interstitial tissue, and produce pronounced inflammation (as evidenced by increased haemocyte numbers). The higher levels of glycogen found in infected crabs also suggest abnormal carbohydrate metabolism. Trypanorhynch infection may also impair the immune system, making the host susceptible to other infections.

Carcinus maenas found in Swan Bay, Victoria were more heavily infected with trypanorhynchs than $C$. maenas from other sites in Victoria, Flinders Island and Tasmania (A. M. Kuris \& R. H. Gurney unpubl. data). The abundance of C. maenas was lowest from Swan Bay (Victoria), where intensity and prevalence of infection was highest. Though the low green crab abundance at Swan Bay may be due to a range of factors, the high prevalence of trypanorhynch infections may be a contributor, either directly by the pathology associated with this infection or indirectly by making hosts more susceptible to infection by other pathological agents, reducing their ability to withstand environmental stressors.

Acknowledgements. We thank Dr. Ian Beveridge from the University of Melbourne for the identifying specimens, Dr. Greg Parry from the Marine and Freshwater Research Institute of Victoria for providing laboratory space, and Ms Jacqui Hauler-Winterford from the University of Tasmania for the preparation of histological sections and slides. We also thank the anonymous referees for their comments and suggestions.

\section{LITERATURE CITED}

Bell TA, Lightner DV (1988) A handbook of normal penaeid shrimp histology. World Aquaculture Society, Baton Rouge, FL

Beveridge I (1990) Taxonomic revision of Australian Eutetrarhynchidae Guiart (Cestoda: Trypanorhyncha). Invertebr Taxon 4:785-845

Beveridge I, Campbell RA (1987) Trimacrancanthus gen. nov. (Cestoda: Trypanorhyncha: Eutetrarhynchidae), with redescriptions of T. aetobatidis (Robinson, 1959) comb. nov. and T. binnuncus (Linton, 1909) comb. nov. Trans R Soc South Aust 111:63-171

Bradbury P, Gordon, KC (1991) Connective tissues and stains. In: Bancroft JD, Stevens A (eds) Theory and practice of histological techniques. Churchill Livingstone, New York 
Cake EW (1976) A key to larval cestodes of shallow-water benthic molluscs of the northern Gulf of Mexico. Proc Helminthol Soc Wash 43:160-171

Cook HC (1991) Carbohydrates. In: Bancroft JD, Stevens A (eds) Theory and practice of histological techniques. Churchill Livingstone, New York

Geller JB, Walton ED, Grosholz ED, Ruiz GM (1997) Cryptic invasions of the crab Carcinus detected by molecular phylogeography. Mol Ecol 6:901-906

Gibson R, Barker PL (1979) The decapod hepatopancreas. Oceanogr Mar Biol Annu Rev 17:285-346

Grosholz ED, Ruiz GM (1995) Spread and the potential impact of the recently introduced European green crab, Carcinus maenas in central California. Mar Biol 122:239-247

Jacobs W (1928) Untersuchungen über die Cytologie der Sekretbildung in der Mitteldarmdrüse von Astacuse leptodactylus. Z Zellforsch Mikrosk Anat Abt Histochem 8: $1-62$

Le Roux PJ, Branch GM, Joska MAP (1990) On the distribution, diet and possible impact of the invasive European shore crab Carcinus maenas (L.) along the South African coast. S Afr J Mar Sci 9:85-93

MacKinnon C (1997) Preliminary evaluation of impacts of Carcinus maenas on bivalve populations in Tasmania. In: Thresher RE (ed) Proc 1st Int Workshop Demography, Impacts and Management of Introduced Populations of the European Crab, Carcinus maenas. 20-21 March 1997, CSIRO Marine Laboratories, Hobart, Tasmania, p 48-49

Owens L, Muir P, Sutton D, Wingfield M (1992) The pathology of microbial diseases in tropical Australian Crustacea. In: Subasinghe RP, Arthur JR, Shariff IM (eds) Diseases in Asian aquaculture. Fish Health Section, Asian Fisheries Society, Manilla, p 165-172

Page KM, Stevens A, Lowe J, Bancroft JD (1991) Bone. In: Bancroft JD, Stevens A (eds) Theory and practice of histological techniques. Churchill Livingstone, New York

Editorial responsibility: Timothy Flegel,

Bangkok, Thailand
Palm HW (1997) Trypanorhynch cestodes of commercial fishes from northeast Brazilian coastal waters. Memorias Instituto Oswaldo Cruz 92:69-79

Ratna S, Vinson SB (1983) Cellular immune responses in Arthropoda. Am Zool 23:185-194

Roberts LS, Janovy J (1996) Foundations of parasitology. Wm. C. Brown, Boston, MA

Robaldo RB, Monserrat J, Cousin JCB, Bianchini A (1999) Effects of metacercaria (Digenea: Microphallidae) on the hepatopancreas of Chasmagnathus granulata (Decapoda: Grapsidae). Dis Aquat Org 37:153-157

Ruiz G M (1987) Interactions among shorebird, crab and their invertebrate prey populations. PhD dissertation, University of California, Berkeley

Sakanari J, Moser M (1989) Complete life cycle of the elasmobranch cestode, Lacistorhynchus dollfusi Beveridge and Sakanari, 1987 (Trypanorhyncha). J Parasitol 75: 806-808

Soderhall K, Cerenius L (1992) Crustacean immunity. Annu Rev Fish Dis 2:3-23

Tettlebach S (1986) Dynamics of crustacean predation on the northern bay scallop Argopecten irradians. PhD thesis, University of Connecticut, CT

Torchin ME, Laffferty KD, Kuris AM (2001) Release from parasites as natural enemies: increased performance of a globally introduced marine crab. Biol Invasions 3:333-345

Torchin ME, Laffferty KD, Dobson AP, McKenzie VJ, Kuris AM (2003) Introduced species and their missing parasites. Nature 421:628-630

Walton WC (1997) Preliminary evaluation of the impact of Carcinus maenas upon the native Tasmanian clam (Katelysia scalarina) fishery. In: Thresher RE (ed) Proc 1st Int Workshop on the Demography, Impacts and Management of Introduced Populations of the European Crab, Carcinus maenas. 20-21 March 1997, CSIRO Marine Laboratories, Hobart, Tasmania, p 44-47

Submitted: November 8, 2001; Accepted: October 14, 2003 Proofs received from author(s): January 2, 2004 